УДК351.86:355.457>(477)

Олег Цевельов, кандидат наук з державного управління Департамент воєнної політики та стратегічного планування Міністерства оборони України, м. Київ, ORCID ID 0000-0003-4549-5505

DOI: $10.33099 / 2617-1775 / 2021-02 / 255-267$

\title{
ФОРМУВАННЯ ПОЛІТИКИ ПРОФЕСІЙНОЇ ВІЙСЬКОВОЇ ОСВІТИ В УКРАЇНІ В СУЧАСНИХ УМОВАХ
}

Під впливом глибоких геополітичних та внутрішніх змін українського суспільства, уніфікаиії культури, поширення різного роду інформації, трансформащії в освітньої політиці відбувається значна робота з пере опрацювання підходів до вищої військової освіти Украйни. Всі иฺі перетворення в якості підготовки майбутніх офіџерів відбуваються на тлі критичних змін в забезпеченні наџіональної безпеці держави та розвитку воєнної науки. Актуальність теми щцодо формування нової політики професійної військової освіти значно зростає у зв'язку із змінами чисельності, структури та функиій Збройних Сил України та інших військових формувань, їх підходах до підготовки кваліфікованих кадрів до виконання завдань nід час підготовки та ведення всеохоплюючої оборони держави.

Ключові слова: професійна військова освіта; Збройні Сили; інші військові формування; підготовка військовослужбовців; кваліфікація; спеціалізація.

Постановка проблеми: Питання формування політики професійної військової освіти рахується в тому, що наукові дослідження розвитку системи військової професійної освіти України у взаємодії з основними положеннями національної безпеки досі являються фрагментарними та носять циклічний характер. Взагалі грунтовних робіт щодо формування політики практично відсутні, що також обумовлює необхідність проведення глибокого аналізу нормативної бази та світових практик в контексті освітньої політики, сучасної воєнно-політичної обстановки, у тісної взаємодії із завданнями реформування й будівництва Збройних Сил України та інших військових формувань i забезпечення національної безпеки держави.

Системна криза та переформатування світоустрою загострюють протиріччя всіх рівнів життя, підвищують вірогідність розв'язання війн та здійснення терористичних актів. В сучасних умовах загострення конкуренції за місто у світовій ієрархії через різні геополітичні стратегії ведучих держав не має адекватних рецептів глобального управління - свої інтереси світові лідери відстоюють любою ціною, що призводить до виникнення жорстких конфліктів, деградації відношень між країнами, зменшенню безпеки, посиленню глобального дисбалансу, зростанню критичної маси проблем у сфері глобальної безпеки, активізації екстремістських угруповань та можливості зміни державних кордонів.

Нарощування воєнних загроз для України, поява нових, нетрадиційних підходів до застосування воєнної сили, зміни у системах озброєння, формах $\mathrm{i}$ способах озброєної боротьби, трансформують погляди на роль складових 
сектору безпеки і оборони, підвищують вимоги до їх підготовки та потребують формування нових лідерських якостей.

Оптимізація та реформування Збройних Сил України та інших військових формувань викликає необхідність в оптимізації вищих військових навчальних закладів, корінних змін усій системи професійної військової освіти - від управління ними, до змісту кваліфікації, стандартів та програм, їх глибинного аналізу через призму збройного конфлікту на сході держави та нових загроз національної безпеки України.

Тому основним змістом під час формування політики професійної військової освіти враховується те, що під час іiі реформування необхідно задовольнити збільшені потреби перспективного стану Збройних Сил України та інших військових формувань, забезпечуючи при цьому єдність новацій із збереженням кращих традицій української воєнної школи.

Аналіз останніх досліджень i публікацій: Теоретичну основу дослідження склали наукові праці останніх років за темою функціонування та розвитку військової системи освіти. В роботі були використані нормативноправові акти, що визначають політику забезпечення національної безпеки, оборони та освіти України, а також останні підходи керівництва Міністерства оборони України 3 питань професійної підготовки військовослужбовців, враховуючи досвід провідних країн світу. Проведено аналіз праць таких науковців, як А.В. Балендра, В.А. Горбулін, Д.В. Вітер, О.О. Мітягін, М.М. Телелим, С.Т. Полторак та ін., в яких осмислюються традиційні та нові загрози національним інтересам України, обгрунтовується необхідність посилення воєнного потенціалу, розвитку Збройних Сил України та інших військових формувань у тому числі у підходах до формування військової освіти.

Метою статті $\epsilon$ здійснення аналізу стану та тенденцій розвитку української системи військової професійної освіти, обгрунтування шляхів іiі удосконалення в контексті забезпечення національної безпеки, захисту територіальної цілісності й суверенітету в умовах ведення «гібридної війни», підвищення боєздатності Збройних Сил України та інших військових формувань з урахуванням воєнно-політичної обстановки у світі. У дослідженні представлені пропозиції щодо формування політики професійної військової освіти в контексті оптимальної моделі професійної підготовки військовослужбовців всіх категорій.

Методи дослідження: системний аналіз і синтез, індукція і дедукція, порівняння, класифікація, узагальнення та систематизація.

Виклад основного матеріалу. В сучасних умовах нестабільного розвитку міжнародних відносин та виникнення воєнних загроз перед країнами світу постають все нові вимоги до підготовки військових фахівців з урахуванням останніх війн та військових конфліктів, які відбуваються у різних куточках світу. Упродовж кількох років, перед міжнародним суспільством піднімається тема про нові світові війни, а саме: війна 3 тероризмом, локальні війни та збройні конфлікти всередині країни на тлі міжнаціональних, етнічних та міжконфесійних протиріч. В цих конфліктах на ряду зі старим озброєнням i 
технічними засобами використовуються нові зразки озброєння та техніки, мінно-вибухових пристроїв та інженерних споруд, безпілотних засобів. Отже роль сучасного військовослужбовця очевидна, тому що вона залежить, у першу чергу, від його професіоналізму та підготовленості діяти в умовах реального бою.

Через протистояння Заходу та Росії, зростання воєнної мощі сусідніх держав та наявності реальних воєнних загроз, Україні необхідна інноваційна та високопрофесійна армія, де до підготовки, технічного кругозору i компетентності військових пред'являються вимоги принципово іншого, найсучаснішого рівня. Сучасний підхід до підготовки військових фахівців диктує передумови для створення чітко вираженої поетапної підготовки, яка дозволить протягом усієї служби військовослужбовця підвищувати йому свої професійні якості.

3 початком конфлікту та розв'язання бойових дій на території України виникла необхідність глибокої трансформації змісту навчання у вищих військових навчальних закладах. Проте практично не відбулося змін самого процесу навчання. Форми навчання і види навчальних занять не сприяють напрацюванню лідерських якостей у військовослужбовців тактичного рівня підготовки та слухачів оперативного й стратегічного рівнів. Проте, відмічається значно більший прогрес у питаннях підготовки лідерських якостей лише у сержантського складу. Із підвищенням ролі сержантів в Збройних Силах та інших військових формуваннях, із збільшенням категорії професійних військовослужбовців та початком підготовки сержантського і старшинського складу у військових навчальних центрах сержантського (старшинського) складу лідерські якості корпусу молодших командирів невпинно зростають.

У багатьох вітчизняних фахових виданнях науковцями виділені деякі складові в дослідженні вищої освіти за кордоном, а саме: міжнародний аспект неперервної професійної освіти; спільність і розбіжності професійної підготовки фахівців у Західній Європі (Франції та Німеччини); сучасна політика вищої освіти США й порівняння з огляду на інтереси України; стан і тенденції розвитку освітніх систем інших зарубіжних країн.

Враховуючи різноманітність систем військової освіти таких країн, як США, Франція та Німеччина, для України необхідно визначити ключові категорії, від яких буде залежати подальший процес підготовки офіцерів всіх категорій, а також формування національної політики професійної військової освіти. Це: структура підготовки військових фахівців, підвищення їх кваліфікації, перепідготовка офіцерських кадрів та етапність у підготовці військових спеціалістів на різних освітніх рівнях.

Аналіз системи військової освіти провідних країн світу дає змогу використовувати досвід організації та вдосконалення процесу військової освіти, який $\epsilon$ ефективним для вирішення проблем реформування вітчизняної військової освіти та формувати власні погляди для підвищення навчання офіцерів та інших категорій військовослужбовців Збройних Сил України та інших військових формувань.

Водночас, аналіз систем професійної військової освіти країн - членів 
НАТО вказує на те, що вони мають низку суттєвих відмінностей від нашої системи в питаннях поєднання професійної військової освіти та підготовки військовослужбовців в процесі служби, термінів здобуття освіти та проходження підготовки. Так, у більшості держав - членів НАТО переважає процес проходження професійної військової підготовки, а не військова освіта, що зумовлюється малою чисельністю збройних сил і невеликим державним замовленням.

Система професійної військової освіти складових сектору безпеки і оборони України забезпечує Збройні Сили України, інші військові формування та правоохоронні органи зі спеціальним статусом держави підготовленими офіцерами, сержантським і старшинським складом. Ця система інтегрована в загальнодержавну систему освіти та має у своєму складі університети, академії, військові інститути (в тому числі у складі цивільних закладів вищої освіти), військові коледжі, факультети i кафедри військової підготовки, а також Київський військовий ліцей, низку ліцеїв 3 посиленою військово-фізичною підготовкою, які належать до інших силових та правоохоронних відомств.

Вища освіта держави (рівно як й для становлення військових фахівців) визначається сукупністю систематизованих знань, умінь і практичних навичок, способів мислення, професійних, світоглядних і громадянських якостей, морально-етичних цінностей, інших компетентностей, здобутих у закладі вищої освіти (науковій установі) у відповідній галузі знань за певною кваліфікацією на рівнях вищої освіти, що за складністю є вищими, ніж рівень повної загальної середньої освіти [1].

Основним продуктом системи професійної військової освіти $\epsilon$ висококваліфіковані кадри, від рівня підготовки яких залежить здатність сил оборони України до захисту держави, а відтак спроможність протистояти зовнішній збройній агресії та іншим воєнним загрозам. Система професійної військової освіти на сьогодні перебуває в процесі кардинальних змін відповідно до вимог законодавства України щодо інтеграції держави в європейський політичний, економічний, безпековий, правовий простори, маючи чіткий намір набуття членства в НАТО. Професійна військова освіта у політиці ії формування розглядається за двома основними аспектами, а це: отримання фундаментальних знань, вмінь і навиків - у навчальному закладі; їх розвиток і закріплення під час виконання функціональних обов'язків на посаді через систему підготовки на відповідних курсах перед призначенням на нові посади. [2].

Під впливом загроз та ризиків на забезпечення національної безпеки України росте розуміння необхідності кардинального переосмислення підходів до формування політики професійної військової освіти, переконання в тому, що без їі осмислення та впровадження сучасних підходів неможливо добитися головної мети - забезпечити надійну національну безпеку (розвиток сектору безпеки і оборони країни, захист суверенітету та територіальної цілісності держави та реалізацію її національних інтересів) як невоєнними заходами, так й під час застосування воєнної сили. Важливим чинником перетворень в системі професійної військової освіти є досвід участі Збройних Сил, інших військових формувань та правоохоронних органів зі спеціальним статусом України в 
проведенні антитерористичної операції та Операції об’єднаних сил на Сході держави.

Для досягнення мети щодо створення висококваліфікованих сил безпеки i оборони необхідні розробка і послідовне проведення реалістичної політики професійної військової освіти, підвищення рівня готовності всіх складових оборони держави, зміцнення ऑii обороноздатності, визначення і використання найбільш ефективних можливих форм та способів нейтралізації воєнних загроз. Прагнення до комплексного і взаємозв'язаного обліку перерахованих чинників під час організації функціонування системи військової освіти та забезпечення воєнної безпеки необхідно розглядати їі як механізм, покликаний реалізовувати прийняті в країні концептуальні погляди і політичні установки в області формування політики військової освіти шляхом координації діяльності органів законодавчої, виконавчої влади і всіх інших елементів сектору безпеки та оборони України.

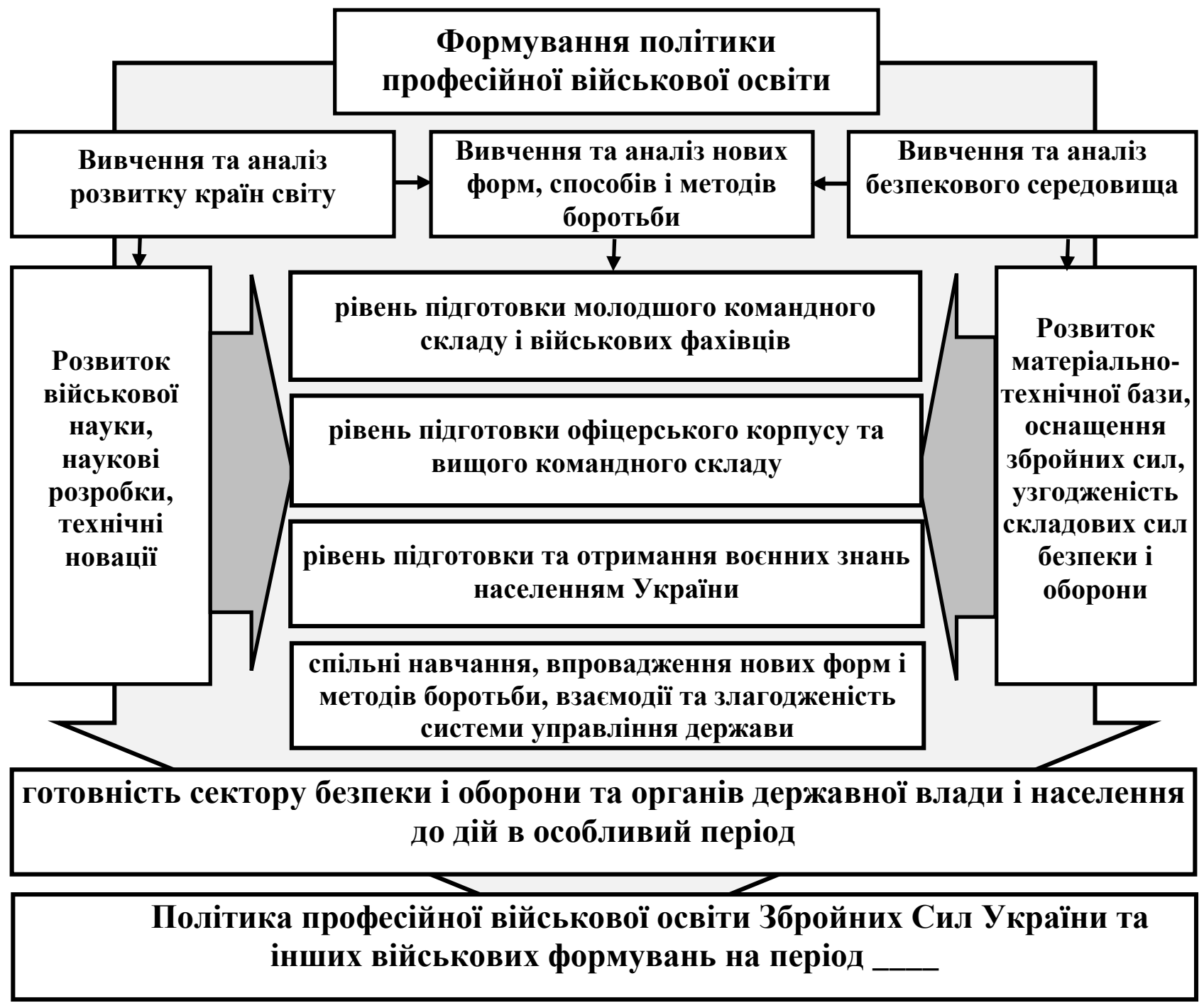

Рис. 1. Шляхи формування політики професійної військової освіти.

Під час формування політики професійної військової освіти повинно враховуватися співробітництво Збройних Сил, інших військових формувань України з країнами НАТО, набуття досвіду та реалізація його в подальшому. 
Метою такої співпраці є:

сприяння у реалізації завдань реформування Збройних Сил України та інших військових формувань відповідно до сучасних стандартів та нарощування їх спроможностей з відбиття збройної агресії проти України;

досягнення сумісності визначених сил та засобів Збройних Сил України 3 військовими формуваннями країн-членів НАТО та партнерів для забезпечення здатності діяти спільно під час проведення операцій з підтримання миру та безпеки та заходів підготовки військ (сил).

Враховуючи сучасний стан військової освіти, проблеми реформування сектору безпеки i оборони України вважаємо, що політика професійної військової освіти повинна включати три основні рівні, а саме: фахівців;

рівень підготовки - корпусу молодшого командного складу і військових

рівень підготовки - офіцерський корпус i вищий командний склад сектору безпеки і оборони держави;

рівень підготовки - для отримання необхідних військових знань і навичок всім населенням України (дивись рис.1).

Реалізуючи ці завдання, Збройні Сили України та інші військові формування використовують увесь спектр існуючих на сьогодні механізмів та програм співробітництва 3 Альянсом, a саме: військовий діалог на стратегічному рівні шляхом участі керівництва Збройних Сил України у щорічних засіданнях Військового комітету НАTO; залучення військовослужбовців України до реалізації програм НАТО, спрямованих на розбудову оборонного потенціалу - Програми удосконалення військової освіти (DEEP), Програми професійного розвитку (PDP) та Ініціативи 3 розбудови доброчесності, прозорості та зниження корупційних ризиків у діяльності оборонних та безпекових інституцій (BI) шляхом участі у відповідних семінарах, курсах, стажуваннях, корабельній практиці тощо; розвиток професійного сержантського складу Збройних Сил України, яка здійснюється за кошти Програми DEEP - консультативно-дорадча підтримка під час розробки навчальних програм для сержантів, проведення програм лідерства, організація заходів фахової та мовної підготовки сержантського складу за стандартами НАТО; набуття сумісності та здатності діяти спільно 3 військовими формуваннями НАТО шляхом виконання завдань, визначених Цілями партнерства для Збройних Сил України у рамках Процесу планування та оцінки сил (ППОС) [3].

Щодо формування сучасної політики професійної військової освіти розглянемо само поняття «професійної військової освіти». Так, професійна військова освіта визначається як одна 3 важливих складових національної безпеки держави. Висококваліфіковані, різностороннє розвинуті та професійні військові кадри різних рівнів структури воєнних формувань - це реальна сила, яка створює оборонний потенціал, зміцнює воєнну міцність.

Поняття «військова освіта» розглядається як сукупність систематизованих знань за фундаментальними та спеціальними знаннями воєнної науки, що необхідні військовослужбовцям під час їх практичної 
діяльності як в мирний час, так у разі ведення бойових дій.

Пилипчук Р.В. наголошує, що військова освіта - «різновид професійної освіти, що має на меті підготовку фахівців 3 різних напрямків військової справи» [4].

Нещадим М.I. визначає, що система військової освіти - «це сукупність взаємопов язаних складових, яка функціонує відповідно до притаманних ій закономірностей і принципів та призначена для підготовки військових фахівців, зміцнення бойової готовності Збройних Сил і створення матеріальних, інтелектуальних і духовних цінностей в інтересах забезпечення національної безпеки та оборони України» [5].

Отже, професійна військова освіта - це процес підготовки громадян України для військової служби та виконання військового обов'язку, підвищення кваліфікації всіх категорій військовослужбовців та перепідготовки військових спеціалістів під час службового зросту чи зміни напрямку службової діяльності, супроводжуючий констатацією досягнутого освітнього рівня.

Військова освіта, передусім, тактичного рівня в усіх провідних країнах світу - це корпоративна система підготовки військових фахівців, призначення яких - виконання завдань, зумовлених специфікою функціонування збройних сил і потребою їх застосування в конкретних умовах.

Як визначає Полторак С.Т., що «державна політика у сфері вищої освіти полягає у формуванні та нормативно-правовому закріпленні загальної стратегії вищої освіти, визначенні цілей, завдань і відповідних напрямків дії, спрямованих на забезпечення функціонування та розвитку системи вищої освіти. Зміст державної політики у сфері вищої освіти визначають мета, завдання, а також основні принципи функціонування та пріоритетні напрямки розвитку системи вищої освіти».

Отже, підготовка персоналу Збройних Сил, інших військових формувань та правоохоронних органів зі спеціальним статусом України - це комплекс заходів, що включає процес навчання, професіоналізації і виховання усіх військовослужбовців, працівників силових відомств України, резервістів, які проходять службу у резерві [6].

Виходячи з визначення системи професійної освіти в основу подальшого ii реформування та формування політики окреслено наступні напрями: законодавче та нормативне врегулювання питань підготовки військових фахівців 3 урахуванням досвіду проведення антитерористичної операції/операції Об'єднаних сил; підвищення якості та приведення змісту і технологій навчання фахівців у відповідність до сучасних завдань сил оборони держави; подальша оптимізація мережі військових навчальних закладів усіх рівнів акредитації, поліпшення підготовки науково-педагогічних кадрів, перехід на більш сумісну 3 країнами НАТО триступеневу систему рівнів військової освіти (тактичний, оперативний і стратегічний рівні); перегляд змісту освіти та фахової підготовки, наполегливе впровадження в освітній процес процедур НАТО тощо.

За ствердженням фахівців департаменту військової освіти i науки 
Міністерства оборони України вважалося, що суто технічне викладання низки військових і цивільних дисциплін та сам процес навчання у військовому середовищі (форма, статути і т.п.) мають підготувати майбутнього офіцера до служби за обраною спеціальністю на первинних посадах у Збройних Силах та інших силових структурах. Навчання на командних факультетах чи вищих навчальних закладах відрізнялося від технічних чи інших спеціалізацій лише кількістю годин, які виділяються на тактику, чи інші дисципліни. Такі дисципліни, як менеджмент не вивчалися. В дисциплінах, які стосувалися управління військами, викладалися лише технічні моменти організації та роботи пунктів управління, порядку роботи командира та деякі аспекти взаємовідношень у військових колективах. Зміст навчання швидше відповідав на питання що потрібен робити командир, проте не давав відповіді на інше - як командир повинен достигати того рішення, яке прийнято та затверджено [7].

Із розвитком зв'язків із західними країнами у військовій освіті, особливо 3 початком гібридної війни, виник інтерес до західної концепції лідерства. Іноземні інструктори почали впроваджувати в Збройних Силах України «курси лідерства» різних рівнів.

Отже, з 2021 року за рішенням відповідного департаменту Міністерства оборони України планується перейти на перспективну систему професійної військової освіти, яка передбачає серйозну кореляцією з кар'єрою офіцера, коли кожному наступному призначенню на вищу посаду передує обов'язкове підвищення рівня військової освіти.

При цьому враховується, що в умовах швидких змін, що відбуваються у воєнній та науково-технічній сферах та через стрімке старіння освітнього контенту, тривалі періоди навчання офіцерів у вищих військових навчальних закладах $\epsilon$ невиправдано фінансово обтяжливими для держави. На зміну тривалим 2-3-річним циклам навчання офіцерських кадрів в університеті, які часто не достатньо пов'язані з офіцерською кар'єрою та не забезпечують отримання актуальних знань та умінь, вводиться системне оновлення професійних компетентностей відповідно до необхідного рівня військової освіти кожні 3-5 років служби офіцерів.

Також Міністерством оборони України внесено пропозиції щодо змін законодавства про освіту, якими, починаючи з 2021 року передбачається введення тактичного, оперативного та стратегічного рівнів, як це впроваджено у країнах-членах НАТО. Для реалізації зазначеної концепції запроваджується система курсів для здобуття відповідного рівня військової освіти (дивись puc. 2). 


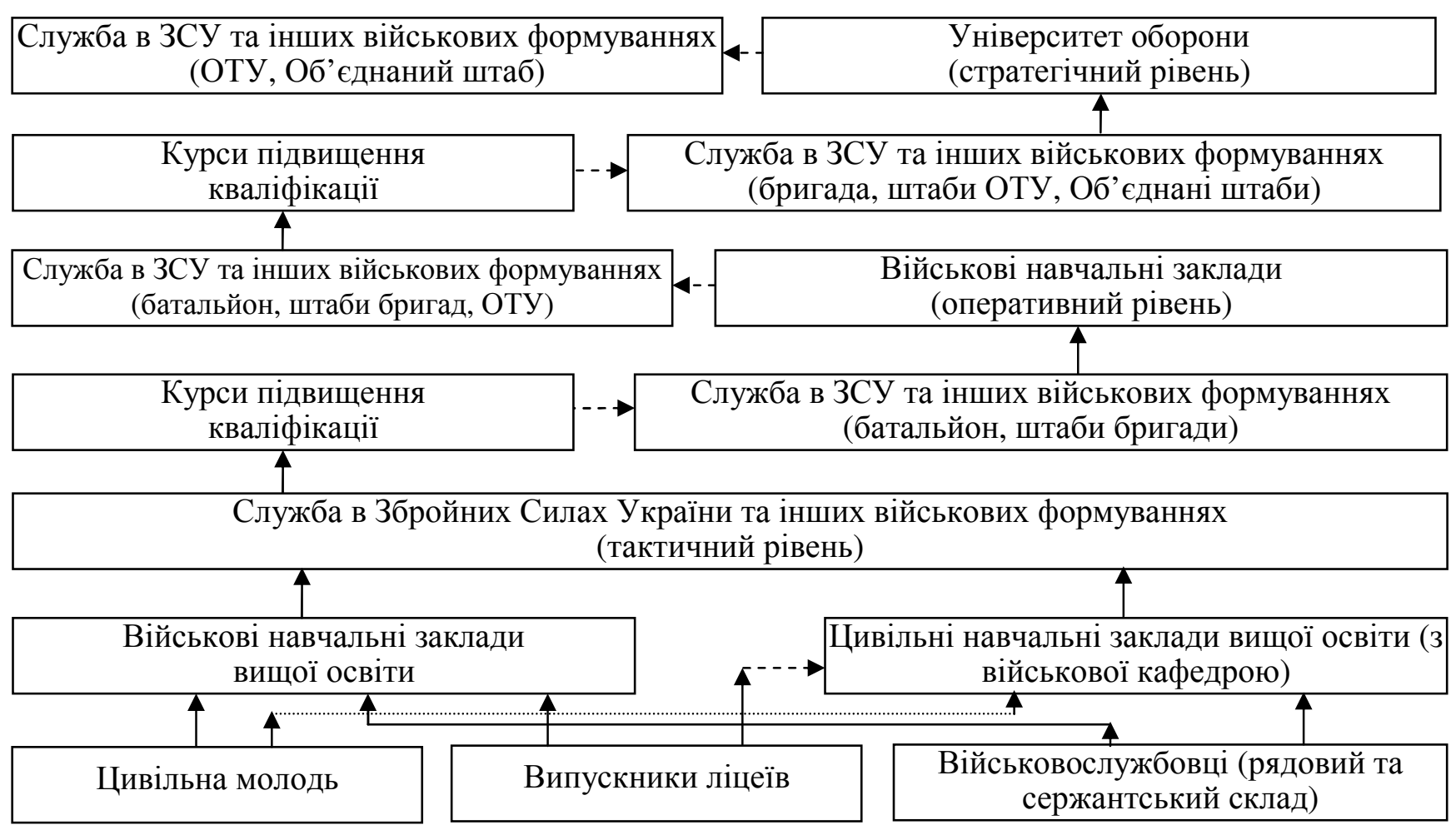

Рис 2. Система професійної підготовки офіцерів Збройних Сил України та інших військових формувань (Варіант)

На сьогодні з врахуванням досвіду країн НАТО реалізовуються три рівні курсів: L-2, L-3, L-4. На L-2 буде вивчатись бригадна тематика, а на L-3 виключно оперативна: навчання слухачів відбуватиметься в об'єднаних, змішаних групах без урахування спеціалізації, оскільки оперативний рівень передбачає ведення об'єднаних, міжвидових операцій і, відповідно, пов'язану з цим специфіку організації освітнього процесу. Відповідно, L-4 - це стратегічний рівень. Крім суто структурних змін, запроваджуються серйозні змістові зміни, якими передбачено розмежування між оперативним та стратегічним рівнями. Основу оперативного рівня становитимуть питання операційного планування та ведення всього спектру об'єднаних операцій, а стратегічного - основи оборонного менеджменту, оборонного планування та прийняття стратегічних рішень у безпековому секторі, діяльність Об'єднаних штабів.

Такий підхід у підготовки офіцерів, які вже здобули освітній рівень магістра, не дає повторно отримувати цей освітній ступінь одночасно зі здобуттям оперативного або стратегічного рівня військової освіти. Для офіцерів, які просуваються по службі, запропоновані курси підвищення кваліфікації, тобто, офіцер здобуває професійну кваліфікацію «професіонал у сфері оборони, офіцер оперативного рівня» або «офіцер стратегічного рівня» чи «офіцер з безпеки державного кордону оперативного рівня», як складову повної освітньої кваліфікації. Таким чином, підчас навчання, реалізується стандарт вищої освіти. 
Практика подальшої підготовки офіцерів буде вдосконалена та продовжена, а терміни навчання на лідерських (оперативних та стратегічних) курсах враховуватимуться як частину магістерської програми, водночас у офіцерів з'являється можливість займатися науковою, дослідницькою діяльністю. Ті офіцери, які не отримали на тактичному рівні освітнього ступеня «магістр», а випускаються з вищих військових навчальних закладів тактичного рівня зі ступенем «бакалавр», матимуть змогу після завершення курсу оперативного або стратегічного рівня, вступити до магістратури за спеціальностями у галузі знань «Воєнні науки, національна безпека, безпека державного кордону», які ліцензовані та акредитовані [8].

Основні напрями реформування та вдосконалення сектору безпеки i оборони України визначаються загальною орієнтацією на підвищення його ефективності, професійної та спільної підготовки всіх складових, зміцнення морально психологічного стану, покращення матеріально-технічного i соціального забезпечення.

Особливо цікавими є погляди на лідерство керівників воєнних відомств країн-членів НАТО. Колишній командувач Об'єднаними збройними силами Коаліції в Афганістан, Центральним Командування збройних сил США та колишній директор ЦРУ Девід Петреус звертає увагу на «культуру розуміння», яка існує у військово-навчальних закладах країн Заходу, як необхідного елементу для визначення проблем, пізнання їх причин і суті, визначення шляхів ïх вирішення та запуску внутрішньо-військових механізмів їх уникнення для впровадження у навчання, тренувальний процес, бойові процедури [9].

Деякі канадські військові лідери вбачають основними складовими підготовки військових лідерів формування критичного погляду на події на базі широкої загальної культури [10], під якою розуміють соціальні науки (соціологію, політологію, антропологію, географію і т.п.), а також літературу, теорію комунікацій, риторику, філософію. Інші зосереджуються на класичній для західного світу теорії трансформаційного лідерства [11] добавляючи до нього елемент інклюзивності, ролі командира у залученні всіх до виконання завдання.

Безумовно, вихованню лідерів сприятиме запровадження передових методів навчання та видів навчальних занять. Операції ЗС України протягом ATO та ООС (оборона Донецького та Луганського аеропортів, бойові дії під Дебальцевим, рейдові дії, звільнення Слов'янська тощо) повинні стати навчальними матеріалами, кейсами для критичного розбору і пошуку кращих рішень у ситуаціях, які склалися. Проблемний метод навчання у поєднанні 3 роботою у групах, призначенням лідерів груп сприятиме розвитку лідерських якостей та засвоєнню групових методів опрацювання рішення. Варто зауважити, що процес прийняття рішення в Збройних Силах України та інших військових формуваннях центрований на особі командира, на противагу до західної військової культури, де значно більше уваги приділяється штабним оцінкам та опрацюванню варіантів рішення. Роль командира (лідера) при такому варіанті роботи за стандартами НАТО та в парадигмі трансформаційного лідерства полягає у: представленні мети майбутніх дій, 
заохоченні до участі, залученні компетентних підлеглих до прийняття рішення, організації спільних дій, керівництві діяльністю штабу [12].

Формування широкої загальної культури має відбуватися викладанням низки дисциплін, які належать до соціальних наук та обов'язковим списком для вивчення спеціалізованої літератури 3 соціології, військової історії, міжнародних відносин, стратегічних комунікацій. Адже поряд із міжнародним виміром діяльності сучасного офіцера (взаємодія із НАТО, спільні навчання, конференції, діяльність іноземних радників) $є$ i абсолютно невідомий майбутнім офіцерам внутрішній соціальний вимір української гібридної війни (історія Донбасу, соціологія конфлікту, право ведення війни, антитерористичне законодавство, протидія тероризму та миротворчі операції).

Без такого масиву знань логіка рішень майбутніх командирів чи спеціалістів у сфері національної безпеки може бути недолугою чи відверто злочинною. Важливою задачею військової освіти провідних держав є освоєння офіцерами таких функцій військово-професійної діяльності, які відповідали б загальнолюдським, демократичним цінностям. Без цих основ не мисляться довірчі відносини між військовою та цивільною частинами суспільства.

Висновки. По-перше, системи військової освіти на сучасному етапі виступає водночас як об'єктом, так і суб'єктом реформування всього комплексу сил оборони. Саме висока якість підготовки військових кадрів $є$ важливою умовою своєчасності, повноти та ефективності виконання заходів оборонної реформи в державі та є основою у формуванні політики професійної військової освіти держави.

По-друге, через наближення системи військової освіти України до євроатлантичних стандартів політика професійної військової освіти повинна включати: перехід на трьохрівневу систему освіти (тактичний, оперативний, стратегічний); запровадження «школи оборонного менеджменту» та «школи лідерства» як складових професіоналізації освіти; перегляд кваліфікаційних вимог і штатно-посадових категорій до військових посад офіцерського складу 3 урахуванням освітніх ступенів і рівнів військової освіти; перегляд змісту освіти та фахової підготовки особового складу.

\section{ЛITЕРАТУРА}

1. Закон України «Про вищу освіту» від 1 липня 2014 p. №1556-VII : URL : http://zakon4.rada.gov.ua/laws/show/1556-18/page2.

2. Натівський аудит професійної військової освіти в міністерстві оборони України. Укринформ. Інтернет-видавництво: URL: https://ukrinform.ua/rubric-society/3074913ukrainsku-vijskovu-jsvitu-reformuut-za-standartami-nato.htm.

3. Програма НАTO 3 удосконалення військової освіти (DEEP): URL: https://nato.int/cps/en/natohg/news_179718.htm.

4. Р. В. Пилипчук. Військова освіта // Енциклопедія Сучасної України: електронна версія [веб-сайт] / гол. редкол.: І.М. Дзюба, А.І. Жуковський, М.Г. Железняк та ін.; НАН України, HTШ. Київ: Інститут енциклопедичних досліджень HAH України, 2006. URL: http://esu.com.ua/search_articles.php?id=34459.

5. Нещадим Микола Іванович. Військова освіта України: історія, теорія, методологія, практика: дис... д-ра пед. наук: 13.00.04 / Інститут педагогіки і психології професійної освіти АПН України. - К., 2004. 
6. С.Т. Полторак. Проблеми державного управління системи вищої військової освіти та шляхи їх вирішення // Інвестиції: практика та досвід. Видавництво ТОВ «ДСК-центр» / №20, 2017 - С.63-66.

7. Офіційний веб сайт Міністерства оборони України : URL : https://mil.gov.ua/news/2021/01/29/novij-algoritm-zdobuttya-vijskovoi-osviti-navchannya-oficzerahrotyagom-usiei-kareri.

8. Ю. Приходько. Підготовка військових фахівців у провідних країнах світу: основоположні засади та тенденції // Педагогічні науки: теорія, історія, інноваційні технології, 2017, № 3 (67) - C.285-299.

9. Petraeus D. Pour un surge des idées / D. Petraeus // Penser autrement : pour une approche critique et créative des affaires militaires: Les Cahiers de la Revue Défense Nationale : URL : https://ru.calameo.com/books/ 00055811533cd3636d191.

10. Parenteau D. La culture générale comme école de commandement: quelle formation pour nos jeunes officiers? / D. Petraeus // Revue militaire canadienne. - 2014. - Vol. 15, No. 1. P. 59-63.

11. Harding J. Les principes fondamentaux du leadership inclusif / J. Harding // Revue militaire canadienne - 2016. - Vol. 16, No. 4. - P. 62-67.

12. Верстюк I. Одкровення генерала. Екс-голова ЦРУ в інтерв'ю НВ пояснює, як Україна може завдати Росії нищівного удару: журнал HB. - 02.07.2019. : URL : http:// nbuv.gov.ua/UJRN/Nzipiend_2010_1_9.

13. Sylvain Paile. European Education And Training For Young Officers The European Initiative For The Exchange Of Young Officers, Inspired By Erasmus. : Brussels, March 2014. P - 38.

\section{REFERENCES}

1. Pro vishy osvity: Zakon Ukrainu vid 1 lipnya 2014 p. №1556-VII : URL : http://zakon4.rada.gov.ua/laws/show/1556-18/page2.

2. Natovskij aydit profesijnoi vijskovoi osvitu v Ministerstvi oboronu Ukreinu. Ukrinform. Internet-vudavnitstvo: URL: https://ukrinform.ua/rubric-society/3074913-ukrainsku-vijskovujsvitu-reformuut-za-standartami-nato.htm.

3. Programa NATO $\mathrm{z}$ udoskonalennya vijskovoi osvitu (DEEP): URL: https://nato.int/cps/en/natohg/news_179718.htm.

4. R.V. Pilipchyk. Vijskova osvita // Entsiklopedia Sychasnoi Ukrainu: elektronnya versia [veb-sait] / gol. redkol.: I.M. Dzuba, A.I. Djykovskij, M.G. Djelezniak ta in.; NAN Ukrainu, NTSH. Kyiv: Instityt entsiklopedichnux doslidgen NAN Ukrainu, 2006. URL : http://esu.com.ua/search_articles.php?id=34459.

5. Nechadim Mukola Ivanovich. Vijskova osvita Ukrainu: istoria, teoria, metodologia, praktika: dis... d-ra ped. nayk: 13.00.04 / Instityt pedagogiku I psixologii profesijnoi osvitu ANP Ukrainu. - K., 2004.

6. S.T. Poltorak. Problemu derjavnogo ypravlenia sistemu vushoi vijskovoi osvitu ta chliaxu ix vurishennia // Snvestutsii: praktika ta dosvid. Vudavnitstvo TOV «DSK-tsentr» / №20, 2017 C.63-66.

7. Ofitsijnui veb sait Ministerstva oboronu Ukrainu: URL: https://mil.gov.ua/news/2021/01/29/novij-algoritm-zdobuttya-vijskovoi-osviti-navchannya-oficzerahrotyagom-usiei-kareri.

8. U. Prixodko. Pidgotovka vijskovux fexivtsiv u providnux krainach svity: osnovopolodgni zasadu ta tendentsii // Pedagogichni nayki: teoria, istoria, innovatsijni technologii, 2017, № 3 (67) C.285-299.

9. Petraeus D. Pour un surge des idées / D. Petraeus // Penser autrement : pour une approche critique et créative des affaires militaires: Les Cahiers de la Revue Défense Nationale: URL: https://ru.calameo.com/books/ 00055811533cd3636d191.

10. Parenteau D. La culture générale comme école de commandement: quelle formation pour nos jeunes officiers? / D. Petraeus // Revue militaire canadienne. - 2014. - Vol. 15, No. 1. 59-63.

11. Harding J. Les principes fondamentaux du leadership inclusif / J. Harding // Revue 
militaire canadienne - 2016. - Vol. 16, No. 4. - P. 62-67.

12. Verstuk I. Odkrovenia generala.Eks-golova TsRU v interviu NB poiasnue, iak Ukraina moje zavdatu Rosii nushivnogo ydary: jurnal NB. - 02.07.2019.: URL: http:// nbuv.gov.ua/UJRN/Nzipiend_2010_1_9.

13. Sylvain Paile. European Education And Training For Young Officers The European Initiative For The Exchange Of Young Officers, Inspired By Erasmus: Brussels, March 2014. P - 38.

Oleg Tsevelyov candidate of sciences in public Administration

Department of military policy and strategic planning of the Ministry of Defense of Ukraine, Kyiv

\section{Formation of professional policy of military education in ukraine in modern conditions}

Introdaction. Under the influence of profound geopolitical and internal changes in Ukrainian society, the unification of culture, the dissemination of various kinds of information, and the transformation of educational policy, considerable work is being done to revise approaches to higher military education in Ukraine.

The issue of forming a policy of vocational military education is considered to be that scientific research into the development of the system of military vocational education in Ukraine in cooperation with the basic provisions of national security is still fragmentary, often empirical.

Purpose. Is to analyze the state and trends of the Ukrainian system of military vocational education, substantiate ways to improve it in the context of national security, protection of territorial integrity and sovereignty in a "hybrid war", increase the combat capability of the Armed Forces and other military formations of Ukraine situation in the world. The study presents proposals for the formation of a policy of professional military education to build an optimal model of professional training of officers.

Methods: system analysis and synthesis, induction and deduction, comparison, classification, generalization and systematization.

Results: Optimization and reform of the Armed Forces of Ukraine and other military formations necessitates the optimization of the network of higher military educational institutions, radical changes in the entire system of professional military education - from their management to the content of training standards and programs, their in-depth analysis through the prism of armed conflict in the east new threats to Ukraine's national security.

Therefore, the main content in shaping the policy of professional military education is that during its reform it is necessary to meet the increased needs of long-term accounting of the Armed Forces of Ukraine and other military formations, while ensuring the unity of innovations while preserving the best traditions of Ukrainian military school.

Originality: The urgency of the topic of forming a new policy of professional military education is growing significantly due to changes in the number, structure and functions of the Armed Forces of Ukraine and other military formations, their approaches to training qualified personnel to perform tasks during training and comprehensive defense.

Conclusion. System of military education at the present stage is both the object and the subject of reform of the whole complex of defense forces.

The most significant measures to bring Ukraine's military education system closer to EuroAtlantic standards should be considered: transition to a three-tier education system; introduction of "school of defense management" and "school of leadership" as components of professionalization of education; revision of qualification requirements and staff categories for military positions of officers, taking into account educational degrees and levels of military education; review of the content of education and professional training of personnel.

Key words: professional military education; Armed Forces; other military formations; training of servicemen; qualification; specialization. 